\title{
Optimal Design of Axially Loaded RC Columns
}

\author{
G. Preethi and Prince G. Arulraj
}

\begin{abstract}
The aim of this investigation is to achieve optimal design of reinforced concrete columns. Optimal design of columns gives economical results in cost saving. This optimum results provides the designers to indentify the best design for the structures. The most economic structure means that could able to withstand the structure without impairing any damages and supposed to serve as a best design of a structure. The objective function is the total cost of the column. The cost of each column includes the cost of concrete and reinforcement. The optimization process is done for different grade of concrete and diameter of rods. The optimal design is carried out using MATLAB's (The Mathworks, Inc.) software. Optimization problem is formulated which is a Nonlinear constrained minimization problem. This is solved using fmincon SQP Algorithm. Each of the designed columns was handled by fmincon SQP Algorithm solver according to its loading condition specifications. Many solved examples are developed and proved that the optimal design is economical. Also it is proved that the developed program is efficient and versatile.
\end{abstract}

Keywords--- Optimization, Nonlinear Programming Problem, Constrained Nonlinear Minimization, SQP Algorithm, Matlab, Columns

\section{INTRODUCTION TO OPTIMIZATION OF RC ELEMENTS}

$\mathrm{O}$ PTIMIZATION is the process of finding a minimum or maximum value of a function for some constraints. The optimization approach is based on the design of reinforced concrete columns. Optimum design of reinforced concrete elements plays an important role in economical design of reinforced concrete structures. An attempt has been made to achieve the optimal design of RC columns can be done by using matlab software. The optimization problem is resolved by formulating the design variables for the structural elements. The objective function was the total cost of the concrete element is the sum of the costs of its constituent materials, the transportation cost, fabrication, mixing, placing, compacting and curing cost. During the present study, Optimization process is done for different grades of concrete and diameter of rods. The optimization problem is a Constrained Nonlinear minimization problem and is solved by using fmincon SQP Algorithm of matlab. The cost function represent the cost of concrete and reinforcement. The results obtained from the analytical study is carried out based on effect of grade of concrete and diameter of reinforcement is achieved with minimum cost construction. Design of RC column has been ensured under the provision of IS : 456-2000. Many solved

G. Preethi, PG Scholar, Dept. of Civil Engineering, SNS College of Technology, Coimbatore.E-mail:mepreethi16@gmail.com

Prince G. Arulraj, Dean, Dept. of Civil Engineering, SNS College of Technology,Coimbatore.E-mail:deancivil@snsct.org

DOI: 10.9756/BIJIEMS.7345 examples are developed for the design optimization of columns. In such a situation an optimization procedure can help designers to find the best design or at least, a good design among different possible designs. The efficiency of the sqp algorithm was examined and found to be good. All the examples proved that the results are economical and gives minimum construction cost.

\section{FORMULATION OF OPTIMIZATION PROBLEM}

In a more advanced formulation, the objective function, $\mathrm{f}(\mathrm{x})$, to be minimized or maximized, might be subject to constraints in the form of equality constraints, $\mathrm{G}_{\mathrm{i}}(\mathrm{x})=0$ ( $\left.\mathrm{i}=1, \ldots, \mathrm{m}_{\mathrm{e}}\right)$; inequality constraints, $\mathrm{G}_{\mathrm{i}}(\mathrm{x}) \leq 0\left(\mathrm{i}=\mathrm{m}_{\mathrm{e}}+1, \ldots, \mathrm{m}\right)$; and/or parameter bounds, $\mathrm{x}_{\mathrm{l}}, \mathrm{x}_{\mathrm{u}}$.

The general optimization problem has the form given in Equation (1)

$$
\min _{x} f(x)(1)
$$

subject to

$$
\begin{gathered}
\mathrm{G}_{\mathrm{i}}(\mathrm{x})=0 \mathrm{i}=1, \ldots, \mathrm{m}_{\mathrm{e}} \\
\mathrm{G}_{\mathrm{i}}(\mathrm{x}) \leq 0 \mathrm{i}=\mathrm{m}_{\mathrm{e}}+1, \ldots, \mathrm{m} \\
\mathrm{x}_{\mathrm{l}} \leq \mathrm{x} \leq \mathrm{x}_{\mathrm{u}}
\end{gathered}
$$

Equality constraints are called $\mathrm{m}_{\mathrm{e}}$.

\section{OPTIMIZATION OF RC COLUMNS}

Optimization of RC columns are used to examine the advantages of a design such as minimum construction cost. Which gives safety, serviceability and economy of a structure. Some restrictions, called design constraints, may limit the acceptable values of the design variables.

\section{A. Objective Function}

The objective function is a criterion by which one or many acceptable designs are preferred to others. It is often assumed that the objective function has to be minimized but in some cases maximization of the objective function (e.g. maximization of mechanical efficiency) is aimed. Although in many cases the weight of structure is considered as the objective function. The total cost of RC structure is considered as the objective function. In general, the cost function may include the initial cost, maintenance cost and expected failure cost. In this research the minimization of the cost of the column is carried out.

\section{B. Design Constraints}

The constraints reflect design requirements in the optimization problem. In other words they limit the range of acceptable designs in the problem. In this research, the constraints relevant to the design of RC column are applied using function. 


\section{Starting Solution}

Starting solution is nothing but initial point where solver begins its search for a minimum value between this ranges.

\section{EFFECT OF CONCRETE GRADE ON THE COST COLUMN}

Optimal Design of RC Columns

In this section, the RC column of cross section is described, showing the fixed parameters, the design variables, the design constraints and the objective function.

Column By Limit State Method ( $\mathrm{b}=230$ (constant), $\mathrm{P}_{\mathrm{u}}=$ variable, Grade of concrete $=$ variable, $f_{y}=415 \mathrm{~N} / \mathrm{mm}^{2}$ )

\section{Objective Function}

$$
\left(X_{1} X_{2}-X_{3}\right) 0.008+X_{3} 0.43175
$$

where:

- $\mathrm{X}_{1}=\mathrm{b}=$ width of column

- $X_{2}=d=$ depth of column

- $\mathrm{X}_{3}=\mathrm{A}_{\mathrm{sc}}=$ Area of longitudinal reinforcement for column

- $0.008=\mathrm{C}_{\mathrm{c}}=$ Cost factor for concrete

- $0.43175=\mathrm{C}_{\mathrm{s}}=$ Cost factor for steel

\section{Design Constraints}

i. Axial load on the member

$$
0.4 \mathrm{f}_{\mathrm{ck}} \mathrm{A}_{\mathrm{c}}+0.67 \mathrm{f}_{\mathrm{y}} \mathrm{A}_{\mathrm{sc}} \geq \mathrm{P}_{\mathrm{u}}
$$

ii. Maximum reinforcement percentage is incorporated in the following constraint

$$
\mathrm{X}_{3} / \mathrm{X}_{1} \mathrm{X}_{2} \leq 0.06
$$

iii. Minimum reinforcement percentage is incorporated in the following constraint

$$
\mathrm{X}_{3} / \mathrm{X}_{1} \mathrm{X}_{2} \geq 0.008
$$

iv. Width of the column

$$
X_{1}=230
$$

Starting Solution

$$
X_{0}=\left[\begin{array}{lll}
200 & 200600
\end{array}\right]
$$

where:

- $\mathrm{A}_{\mathrm{sc}}=$ Area of longitudinal reinforcement for column

- $\mathrm{A}_{\mathrm{c}}=$ Area of concrete

- $\mathrm{A}_{\mathrm{g}}=$ Gross area of concrete section

- $\mathrm{P}_{\mathrm{u}}=$ Factored axial load on the member

- $\mathrm{f}_{\mathrm{ck}}=$ Characteristic compressive strength of the concrete

- $\mathrm{f}_{\mathrm{y}}=$ Characteristic strength of the compression reinforcement

- $\quad \mathrm{X}_{1}=\mathrm{b}=$ width of column

- $\mathrm{X}_{2}=\mathrm{d}=$ depth of column

- $\mathrm{X}_{3}=\mathrm{A}_{\mathrm{sc}}=$ Area of longitudinal reinforcement for column

\section{MATLAB Programs}

Objective Function

function $\mathrm{f}=$ objfun $(\mathrm{x})$

$\mathrm{f}=(\mathrm{x}(1) * \mathrm{x}(2)-\mathrm{x}(3)) * 0.008+\mathrm{x}(3) * 0.43175$;

end

\section{Constraints}

function $[\mathrm{c}, \mathrm{ceq}]=\operatorname{confun}(\mathrm{x})$

$\mathrm{c}=\left[-8 *(\mathrm{x}(1) * \mathrm{x}(2)-\mathrm{x}(3))-278.05 * \mathrm{x}(3)+7.5 * 10^{\wedge} 5\right.$;

$-0.06+\mathrm{x}(3) /(\mathrm{x}(1) * \mathrm{x}(2))$

$-\mathrm{x}(3) /(\mathrm{x}(1) * \mathrm{x}(2))+0.008]$;

ceq $=\mathrm{x}(1)-230$;

end

The output of the above function is given in following Tables

\section{Effect of Grade of Concrete on the Cost of Column}

In order to determine the effect of grade of concrete on the cost of R.C columns, the optimal design of columns were found for various grade of concrete. The details of the optimal design are given in Table 1 for the factored load of $750 \mathrm{kN}$

Table 1: Optimal Results for the Design of Columns for a Factored Load of $750 \mathrm{kN}$

\begin{tabular}{|l|l|l|l|l|}
\hline Grade of Concrete & $b(\mathrm{~mm})$ & $d(\mathrm{~mm})$ & $A_{s c}\left(\mathrm{~mm}^{2}\right)$ & $\operatorname{Cost}(\mathrm{Rs})$ \\
\hline M20 & 230 & 320.94 & 590.53 & 840.76 \\
\hline M25 & 230 & 268.51 & 494.06 & 734.04 \\
\hline M30 & 230 & 230.80 & 424.68 & 657.29 \\
\hline M35 & 230 & 230 & 423.2 & 602.53 \\
\hline M40 & 230 & 230 & 423.2 & 602.53 \\
\hline M45 & 230 & 230 & 423.2 & 602.53 \\
\hline M50 & 230 & 230 & 423.2 & 602.53 \\
\hline
\end{tabular}

From Table 1, it can be seen that the cost of the column is least when $\mathrm{M}_{35}$ grade of concrete is adopted.

The results of the optimization problem for a factored load of $1000 \mathrm{kN}$ is given in Table 2

Table 2: Optimal Results for the Design of Columns for a Factored Load of $1000 \mathrm{kN}$

\begin{tabular}{|l|l|l|l|l|}
\hline Grade of Concrete & $b(\mathrm{~mm})$ & $d(\mathrm{~mm})$ & $A_{s c}\left(\mathrm{~mm}^{2}\right)$ & Cost $(\mathrm{Rs})$ \\
\hline M20 & 230 & 427.92 & 787.37 & 1121.02 \\
\hline M25 & 230 & 358 & 658.74 & 978.72 \\
\hline M30 & 230 & 307.74 & 566.24 & 876.39 \\
\hline M35 & 230 & 269.84 & 496.51 & 800 \\
\hline M40 & 230 & 240.26 & 442.08 & 739.04 \\
\hline M45 & 230 & 230 & 423.2 & 602.53 \\
\hline M50 & 230 & 230 & 423.2 & 602.53 \\
\hline
\end{tabular}

From Table 2, it can be seen that the cost of the column is least when $\mathrm{M}_{45}$ grade of concrete is adopted.

The results of the optimization problem for a factored load of $1250 \mathrm{kN}$ is given in Table 3 
Table 3: Optimal Results for the Design of Columns for a Factored Load of $1250 \mathrm{kN}$

\begin{tabular}{|l|l|l|l|l|}
\hline Grade of Concrete & $b(\mathrm{~mm})$ & $d(\mathrm{~mm})$ & $A_{s c}\left(\mathrm{~mm}^{2}\right)$ & $\operatorname{Cost}(\mathrm{Rs})$ \\
\hline M20 & 230 & 534.90 & 984.21 & 1401.27 \\
\hline M25 & 230 & 447.51 & 832.43 & 1223.40 \\
\hline M30 & 230 & 384.67 & 707.79 & 1095.49 \\
\hline M35 & 230 & 337.30 & 620.64 & 1000 \\
\hline M40 & 230 & 300.32 & 552.60 & 923.80 \\
\hline M45 & 230 & 270.65 & 498 & 1141.29 \\
\hline M50 & 230 & 246.32 & 453.22 & 1319.66 \\
\hline
\end{tabular}

From Table 3, it can be seen that the cost of the column is least when $\mathrm{M}_{40}$ grade of concrete is adopted.

The results of the optimization problem for a factored load of $1500 \mathrm{kN}$ is given in Table 4

Table 4: Optimal Results for the Design of Columns for a Factored Load of $1500 \mathrm{kN}$

\begin{tabular}{|l|l|l|l|l|}
\hline Grade of Concrete & $b(\mathrm{~mm})$ & $d(\mathrm{~mm})$ & $A_{s c}\left(\mathrm{~mm}^{2}\right)$ & $\operatorname{Cost}(\mathrm{Rs})$ \\
\hline M20 & 230 & 641.88 & 1181.06 & 1681.53 \\
\hline M25 & 230 & 537.02 & 988.11 & 1468.08 \\
\hline M30 & 230 & 461.61 & 849.35 & 1314.59 \\
\hline M35 & 230 & 404.77 & 744.77 & 1198.89 \\
\hline M40 & 230 & 360.78 & 663.12 & 1108.56 \\
\hline M45 & 230 & 324.78 & 597.60 & 1369.54 \\
\hline M50 & 230 & 295.56 & 543.86 & 1583.59 \\
\hline
\end{tabular}

From Table 4, it can be seen that the cost of the column is least when $\mathrm{M}_{40}$ grade of concrete is adopted.

The results of the optimization problem for a factored load of $1750 \mathrm{kN}$ is given in Table 5

Table 5: Optimal Results for the Design of Columns for a Factored Load of $1750 \mathrm{kN}$

\begin{tabular}{|l|l|l|l|l|}
\hline Grade of Concrete & $b(\mathrm{~mm})$ & $d(\mathrm{~mm})$ & $A_{s c}\left(\mathrm{~mm}^{2}\right)$ & $\operatorname{Cost}(\mathrm{Rs})$ \\
\hline M20 & 230 & 748.86 & 1377.90 & 1961.78 \\
\hline M25 & 230 & 626.52 & 1152.80 & 1712.76 \\
\hline M30 & 230 & 538.54 & 990.91 & 1533.68 \\
\hline M35 & 230 & 472.23 & 868.90 & 1398.71 \\
\hline M40 & 230 & 420.45 & 773.64 & 1293.32 \\
\hline M45 & 230 & 378.91 & 697.20 & 1597.80 \\
\hline M50 & 230 & 344.84 & 634.51 & 1847.52 \\
\hline
\end{tabular}

From Table 5, it can be seen that the cost of the column is least when $\mathrm{M}_{40}$ grade of concrete is adopted.

The results of the optimization problem for a factored load of $2000 \mathrm{kN}$ is given in Table 6

Table 6: Optimal Results for the Design of Columns for a Factored Load of $2000 \mathrm{kN}$

\begin{tabular}{|l|l|l|l|l|}
\hline Grade of Concrete & $b(\mathrm{~mm})$ & $d(\mathrm{~mm})$ & $A_{\text {sc }}\left(\mathrm{mm}^{2}\right)$ & Cost $(\mathrm{Rs})$ \\
\hline M20 & 230 & 855.84 & 1574.74 & 2242.04 \\
\hline M25 & 230 & 716.02 & 1317.48 & 1957.45 \\
\hline M30 & 230 & 615.47 & 1132.47 & 1752.78 \\
\hline M35 & 230 & 539.69 & 993.02 & 1598.52 \\
\hline M40 & 230 & 480.52 & 884.15 & 1478.08 \\
\hline M45 & 230 & 433.04 & 796.80 & 1826.06 \\
\hline M50 & 230 & 394.10 & 725.15 & 2111.46 \\
\hline
\end{tabular}

From Table 6, it can be seen that the cost of the column is least when $\mathrm{M}_{40}$ grade of concrete is adopted.

\section{EFFECT OF REINFORCEMENT DIAMETER ON THE COST COLUMN}

In order to determine the effect of diameter of reinforcement on the cost of R.C columns, the optimal design of columns were found for various diameter of reinforcement. The details of the optimal design are given in Table 7 for the factored load of $750 \mathrm{kN}$. The grade of concrete assumed was $\mathrm{M}_{35}$.

Table 7: Optimal Results of Various Diameter of Reinforcement for a Load of $750 \mathrm{kN}$

\begin{tabular}{|l|l|l|l|l|l|}
\hline Dia of Rods & $b(\mathrm{~mm})$ & $d(\mathrm{~mm})$ & $A s c\left(\mathrm{~mm}^{2}\right)$ & $\begin{array}{l}A_{\text {sc pro }} \\
\left(\mathrm{mm}^{2}\right)\end{array}$ & $\begin{array}{l}\text { Cost } \\
(R s)\end{array}$ \\
\hline 12 & 230 & 230 & 423 & 452 & 693 \\
\hline 16 & 230 & 230 & 423 & 603 & 757 \\
\hline 20 & 230 & 230 & 423 & 628 & 768 \\
\hline 25 & 230 & 230 & 423 & 981 & 917 \\
\hline 32 & 230 & 230 & 423 & 1608 & 1181 \\
\hline 40 & 230 & 230 & 423 & 2512 & 1563 \\
\hline
\end{tabular}

From Table 7 , it can be seen that $12 \mathrm{~mm}$ diameter of reinforcement give the least cost.

The results of the optimization problem for a load of $1000 \mathrm{kN}$ for $\mathrm{M}_{45}$ grade of concrete are given in Table 8 .

Table 8: Optimal Results of Various Diameter of Reinforcement for a Load of $1000 \mathrm{kN}$

\begin{tabular}{|l|l|l|l|l|l|}
\hline Dia of Rods & $b(\mathrm{~mm})$ & $d(\mathrm{~mm})$ & $A s c\left(\mathrm{~mm}^{2}\right)$ & $\begin{array}{l}A_{\text {sc pro }} \\
\left(\mathrm{mm}^{2}\right)\end{array}$ & $\begin{array}{l}\text { Cost } \\
(\mathrm{Rs})\end{array}$ \\
\hline 12 & 230 & 230 & 423 & 452 & 982 \\
\hline 16 & 230 & 230 & 423 & 603 & 1045 \\
\hline 20 & 230 & 230 & 423 & 628 & 1055 \\
\hline 25 & 230 & 230 & 423 & 981 & 1202 \\
\hline 32 & 230 & 230 & 423 & 1608 & 1464 \\
\hline 40 & 230 & 230 & 423 & 2512 & 1840 \\
\hline
\end{tabular}

From Table 8 , it can be seen that $12 \mathrm{~mm}$ diameter of reinforcement give the least cost.

The results of the optimization problem for a load of $1250 \mathrm{kN}$ for $\mathrm{M}_{40}$ grade of concrete are given in Table 9.

Table 9: Optimal Results of Various Diameter of Reinforcement for a Load of $1250 \mathrm{kN}$

\begin{tabular}{|l|l|l|l|l|l|}
\hline Dia of Rods & $b(\mathrm{~mm})$ & $d(\mathrm{~mm})$ & $A s c\left(\mathrm{~mm}^{2}\right)$ & $\begin{array}{l}A_{\text {sc pro }} \\
\left(\mathrm{mm}^{2}\right)\end{array}$ & $\begin{array}{l}\text { Cost } \\
(\mathrm{Rs})\end{array}$ \\
\hline 12 & 230 & 300 & 553 & 565 & 929 \\
\hline 16 & 230 & 300 & 553 & 603 & 945 \\
\hline 20 & 230 & 300 & 553 & 628 & 956 \\
\hline 25 & 230 & 300 & 553 & 981 & 1105 \\
\hline 32 & 230 & 300 & 553 & 1608 & 1369 \\
\hline 40 & 230 & 300 & 553 & 2512 & 1750 \\
\hline
\end{tabular}

From Table 9, it can be seen that $12 \mathrm{~mm}$ diameter of reinforcement give the least cost.

The results of the optimization problem for a load of $1500 \mathrm{kN}$ for $\mathrm{M}_{40}$ grade of concrete are given in Table 10. 
Table 10: Optimal Results of Various Diameter of Reinforcement for a Load of $1500 \mathrm{kN}$

\begin{tabular}{|l|l|l|l|l|l|}
\hline $\begin{array}{l}\text { Dia of } \\
\text { Rods }\end{array}$ & $b(\mathrm{~mm})$ & $d(\mathrm{~mm})$ & $A s c\left(\mathrm{~mm}^{2}\right)$ & $\begin{array}{l}A_{\text {sc pro }} \\
\left(\mathrm{mm}^{2}\right)\end{array}$ & $\begin{array}{l}\text { Cost } \\
(\mathrm{Rs})\end{array}$ \\
\hline 12 & 230 & 360 & 663 & 678 & 1115 \\
\hline 16 & 230 & 360 & 663 & 804 & 1168 \\
\hline 20 & 230 & 360 & 663 & 942 & 1226 \\
\hline 25 & 230 & 360 & 663 & 981 & 1243 \\
\hline 32 & 230 & 360 & 663 & 1608 & 1507 \\
\hline 40 & 230 & 360 & 663 & 2512 & 1888 \\
\hline
\end{tabular}

From Table 10 , it can be seen that $12 \mathrm{~mm}$ diameter of reinforcement give the least cost.

The results of the optimization problem for a load of $1750 \mathrm{kN}$ for $\mathrm{M}_{40}$ grade of concrete are given in Table 11 .

Table 11: Optimal Results of Various Diameter of Reinforcement for a Load of $1750 \mathrm{kN}$

\begin{tabular}{|l|l|l|l|l|l|}
\hline Dia of Rods & $b(\mathrm{~mm})$ & $d(\mathrm{~mm})$ & $A s c\left(\mathrm{~mm}^{2}\right)$ & $\begin{array}{l}A_{\text {sc pro }} \\
\left(\mathrm{mm}^{2}\right)\end{array}$ & $\begin{array}{l}\text { Cost } \\
(R s)\end{array}$ \\
\hline 12 & 230 & 420 & 774 & 791 & 1301 \\
\hline 16 & 230 & 420 & 774 & 804 & 1306 \\
\hline 20 & 230 & 420 & 774 & 942 & 1364 \\
\hline 25 & 230 & 420 & 774 & 981 & 1381 \\
\hline 32 & 230 & 420 & 774 & 1608 & 1645 \\
\hline 40 & 230 & 420 & 774 & 2512 & 2026 \\
\hline
\end{tabular}

From Table 11, it can be seen that $12 \mathrm{~mm}$ diameter of reinforcement give the least cost.

The results of the optimization problem for a load of $2000 \mathrm{kN}$ for $\mathrm{M}_{40}$ grade of concrete are given in Table 12 .

Table 12: Optimal Results of Various Diameter of Reinforcement for a Load of $2000 \mathrm{kN}$

\begin{tabular}{|l|l|l|l|l|l|}
\hline Dia of Rods & $b(\mathrm{~mm})$ & $d(\mathrm{~mm})$ & $A s c\left(\mathrm{~mm}^{2}\right)$ & $\begin{array}{l}A_{\text {sc pro }} \\
\left(\mathrm{mm}^{2}\right)\end{array}$ & $\begin{array}{l}\text { Cost } \\
(\mathrm{Rs})\end{array}$ \\
\hline 12 & 230 & 481 & 884 & 904 & 1487 \\
\hline 16 & 230 & 481 & 884 & 1005 & 1529 \\
\hline 20 & 230 & 481 & 884 & 942 & 1502 \\
\hline 25 & 230 & 481 & 884 & 981 & 1519 \\
\hline 32 & 230 & 481 & 884 & 1608 & 1783 \\
\hline 40 & 230 & 481 & 884 & 2512 & 2165 \\
\hline
\end{tabular}

From Table 12, it can be seen that $12 \mathrm{~mm}$ diameter of reinforcement is found to give least cost.

\section{CONCLUSION}

A Matlab program for the optimization of reinforced concrete elements has been developed using Constrained Nonlinear minimization of fmincon SQP Algorithm. The main conclusions drawn from the current research can be summarized as follows:

- The efficiency of the SQP algorithm optimization was examined and found to be good.

- Optimization of R.C Columns indicate that minimum percentage of steel must be used as reinforcement. Higher percentage of steel results in higher cost.

- The effect of grade of concrete on the cost of Columns were studied and it was found that grade of concrete has an impact on the cost of R.C Columns. Here, $\mathbf{M}_{35}$, $M_{40}$ and $M_{45}$ grade of concrete are found to give least cost.
- The effect of diameter of reinforcement on the cost of Columns were studied and it was found that diameter of concrete has an impact on the cost of R.C Columns. Here, $12 \mathrm{~mm}$ diameters of reinforcement are found to give least cost.

\section{REFERENCES}

[1] Andres Guerra and D. Panos Kiousis, "Design Optimization of Reinforced Concrete Structures", Computers and Concrete, Vol. 3, Pp. 313-334, 2006.

[2] H. Sudarsana Rao and B. Ramesh Babu, "Optimized Column Design Using Genetic Algorithm Based Neural Networks", Indian Journal of Engineering \& Materials Sciences, Vol. 13, Pp. 503-511, 2006.

[3] Bikramjit Singh and Hardeep Singh Rai, "Optimisation of RCC Beam", International Journal of Engineering, Business and Enterprise Applications (IJEBEA), Vol. 9, No.1, Pp. 21-34, 2014.

[4] S. Kiran Patil, N.G. Gore, and P.J. Salunke, "Optimum Design of Reinforced Concrete Flat Slab with Drop Panel", International Journal of Recent Technology and Engineering (IJRTE), Vol. 2, No. 4, Pp. 37-39, 2013

[5] Plain and reinforced concrete-code of practice, New Delhi: Bureau of Indian Standards (2000). 